\title{
Hydrogenation of Carbon Monoxide to Light Olefins over Chlorine-Containing Magnetite Catalysts in Slurry Phase ${ }^{\dagger}$
}

\author{
Kiyomi OKaBE ${ }^{\dagger 1) *}$, Kenji SAItoH ${ }^{\dagger 2)}$, Tsuneji SAnO $^{\dagger 1)}$, Yoshiroh Yasumoto ${ }^{\dagger 1)}$, \\ Kin-ya Shimomura ${ }^{\dagger 1}$, Hiroyuki Hagrwara ${ }^{\dagger 1)}$, Haruo Takaya $^{\dagger 1}$, \\ and Ken-ichiroh BANDOH ${ }^{\dagger 1}$ \\ †1) Gatalysis Division, National Chemical Laboratory for Industry, Yatabe, \\ Tsukuba-gun, Ibaraki 305 \\ †2) Maruzen Petrochemical Co., Ltd., Hatchobori, Chuo-ku, Tokyo 104
}

(Received January 18, 1985)

\begin{abstract}
Hydrogenation of carbon monoxide was carried out at $P=10 \mathrm{~atm}, T=325^{\circ} \mathrm{C}$, and $\mathrm{GHSV}=$ $1,000-5,000 \mathrm{~h}^{-1}$ over chlorine-containing magnetite catalysts in the slurry phase. High selectivities to light olefins $\left(\mathrm{C}_{\overline{2}}-\mathrm{C}_{\overline{4}}\right)$ of $48 \%$ with suppression of methane formation to $11 \%$ were obtained with these catalysts. Carbon dioxide, a by-product of the reaction, was hardly produced over the catalysts. The chlorine content in the used catalysts, determined by X-ray fluorescence spectrometry, was in the atomic ratio range of $\mathrm{Cl} / \mathrm{Fe}=0.002-0.01$. The XPS results of the catalysts showed that the surface concentration of chlorine was in the range of $\mathrm{Cl} /$ $\mathrm{Fe}=0.1-0.2$, and that the chlorine on the surface was more negatively charged than that the iron chloride. The chlorine prevented over-reduction of the surface to metallic iron during the reaction. These effects were explained in terms of electron attraction of the chlorine on the surface.
\end{abstract}

\section{Introduction}

We have suggested that, under high pressures and at high temperatures, practical iron-based FischerTropsch (FT) catalysts with high selectivity to olefins are in the form of magnetite-like species.1)

Various promoters are often added to the FT catalysts to enhance the selectivity to light olefins. Potassium salts have been most commonly used for this purpose.2) A small amount of potassium, indeed, enhances olefin selectivity, and depresses methane and paraffin formations by reducing the hydrogenation activity of the catalyst. At the same time, however, the distribution of hydrocarbons shifts toward higher molecular weights. Consequently, the selectivity to light olefins cannot be improved so much by use only of alkaline salt promoters.

We have reported previously that high selectivity to ethylene and propylene was obtained over the magnetite catalysts prepared from iron chlorides

$\dagger$ A part of this study was presented at "The 54th Shokubai Toronkai", (1984).

* To whom correspondence should be addressed. when CO hydrogenation was carried out in a fixed-bed reactor ${ }^{3}$, while, due to its ineffective heat removal, deactivation of the catalyst occurred to some degree.

The purposes of the present paper are : examination of this type of catalysts more in detail, and application of the catalysts to CO hydrogenation in a slurry type reactor, with which the intrinsic characteristics of the catalysts could probably be more precisely evaluated, because the heat of reaction is effectively dissipated in the slurry phase.

\section{Experimental}

\subsection{Preparation of Catalysts}

\subsubsection{Magnetite Prepared by Reflux}

Chlorine-containing magnetite was obtained by reflux of an aqueous solution of ferric chloride in the presence of metallic iron powder at $100^{\circ} \mathrm{G}$ for 1 week.4) The magnetite was treated in a $\mathrm{H}_{2}$ flow at $400^{\circ} \mathrm{C}$ for $10 \mathrm{~h}$ to remove part of the chlorine from it. The treatment was carried out outside the reactor. The magnetite is henceforth called "magnetite by reflux" and abbreviated as $\mathrm{Cl} /$ $\mathrm{Fe}_{3} \mathrm{O}_{4}$. 
2.1.2 Magnetite Prepared by Ammonium Coprecipitation

Magnetite was obtained from an aqueous solution of ferrous and ferric chlorides $(1: 2)$ by co-precipitation with ammonia water. This magnetite is abbreviated as $\mathrm{NH}_{3} \downarrow \mathrm{Fe}_{3} \mathrm{O}_{4}$.

\subsubsection{Chloridized Magnetite}

Ferric oxide hydrate $(\alpha-\mathrm{FeOOH})$ was mechanically mixed with ferric chloride. The mixture $(\mathrm{Cl} / \mathrm{Fe}$ $=0.1$ ) was treated in $\mathrm{H}_{2}$ flow at $350^{\circ} \mathrm{C}$ for $10 \mathrm{~h}$ to be reduced partially to magnetite. This magnetite is henceforth called "chloridized magnetite" and abbreviated as $\mathrm{Cl}-\mathrm{Fe}_{3} \mathrm{O}_{4}$.

\subsubsection{Magnetite from Akaganeite}

Akaganeite $(\beta-\mathrm{FeOOH})$, which is known to contain chloride ion in its micropore, was obtained from an aqueous solution of ferric chloride ${ }^{5}$, and was treated in a $\mathrm{H}_{2}$ flow at $350^{\circ} \mathrm{C}$ for $10 \mathrm{~h}$ to be reduced to magnetite. This magnetite is abbreviated as $\beta$ - $\mathrm{FeOOH}$.

\subsubsection{Magnetite without Chlorine (control)}

Magnetite without chlorine, as a control, was obtained from chlorine-free ferrous hydroxide by air-oxidation. ${ }^{6}$ )

\subsection{Procedure}

Each magnetite catalyst prepared above was crushed into a fine powder which was suspended in a $250 \mathrm{~m} l$ of liquid paraffin (bp. $330-390^{\circ} \mathrm{C}$ ) to form a slurry of the catalyst. Hydrogenation of carbon monoxide was carried out with the slurry catalyst in a semi-batch slurry type reactor (flow type for gas phase). Reaction conditions were as follows : $T=325^{\circ} \mathrm{C} ; P=10$ atm ; $\mathrm{GHSV}=1,000$ $5,000 \mathrm{~h}^{-1}$. The reaction gas had the following composition : $\mathrm{H}_{2}: \mathrm{CO}: \mathrm{Ar}=45: 45: 10$. By using argon concentration in the reaction gas as an internal standard, conversion and carbon-based selectivity were expressed by the following equations :

$$
\begin{aligned}
& \text { CO conv. }=\left(1-\frac{[\mathrm{CO}]}{[\mathrm{Ar}]} \times \frac{[\mathrm{Ar}]_{\mathrm{o}}}{[\mathrm{CO}]_{\mathrm{o}}}\right) \times 100 \\
& C_{n} \text { yield }=\frac{\left[\mathrm{C}_{n}\right]}{[\mathrm{Ar}]} \times n \times \frac{[\mathrm{Ar}]_{\mathrm{o}}}{[\mathrm{CO}]_{\mathrm{o}}} \times 100 \\
& C_{n} \text { selectivity }=\frac{C_{n} \text { yield }}{(\mathrm{CO} \text { conv. })-\left(\mathrm{CO}_{2} \text { yield }\right)}
\end{aligned}
$$

where $[\mathrm{Ar}]$ and $[\mathrm{CO}]$ are the concentrations of $\mathrm{Ar}$ and $\mathrm{CO}$ in the effluent gas, $[\mathrm{Ar}]_{\mathrm{o}}$ and $[\mathrm{CO}]_{\mathrm{o}}$ are the initial concentrations of $\mathrm{Ar}$ and $\mathrm{CO}$ in the reaction gas, and $\left[C_{n}\right]$ is the concentration of the product of which carbon number is $n$, respectively. In this manner, the $\mathrm{CO}$ conversion can be accurately evaluated even though all of the carbonaceous products are not determined. Detailed procedures and analyses of the products were described previously.7)

\subsection{Analyses of Catalysts}

Fresh and used catalysts were identified using an X-ray diffractometer (Rigaku ; Geigerflex RAD). Chlorine in the catalysts was determined using an X-ray fluorescence spectrometer (Philips ; PW 1410). Surfaces of the catalysts were analyzed with an X-ray photoelectron spectroscope (Shimadzu ; ASIX).

\section{Results}

\subsection{Blank Test}

A blank test was carried out by using hydrogen instead of syngas to evaluate the decomposition of the liquid paraffin used as the slurry medium. When the reaction temperature was raised to $350^{\circ} \mathrm{C}$, a trace amount (below $0.01 \mathrm{vol} \%$ ) of $\mathrm{C}_{4}$ and $\mathrm{C}_{5}$ was detected only in the effluent gas over the magnetite catalyst prepared by reflux $\left(\mathrm{Cl} / \mathrm{Fe}_{3} \mathrm{O}_{4}\right)$. The amount was almost equivalent to the limit of accuracy of the gas chromatograph employed.

\subsection{Reaction Results}

Hydrogenation of carbon monoxide was carried out at $P=10 \mathrm{~atm}, T=325^{\circ} \mathrm{C}$, and $\mathrm{GHSV}=1,000-$ $5,000 \mathrm{~h}^{-1}$ in the slurry phase. The results are given in Table 1. Both conversion and selectivity were almost invariable during $20 \mathrm{~h}$.

Carbon monoxide conversion after $\mathrm{H}_{2}$ pretreatment was $8.6 \%$ over the $\mathrm{Cl} / \mathrm{Fe}_{3} \mathrm{O}_{4}$ catalyst (Run 1). However, $\mathrm{CO}$ conversion was less than $2 \%$ over the $\mathrm{Cl} / \mathrm{Fe}_{3} \mathrm{O}_{4}$ catalyst without $\mathrm{H}_{2}$ pretreatment (Run 2). Methane and $\mathrm{C}_{2}-\mathrm{C}_{4}$ olefin $\left(\mathrm{C}_{\overline{\mathbf{2}}}-\mathrm{C}_{\overline{\mathbf{4}}}\right)$ selectivities were $11 \%$ and $48 \%$, respectively. Only a small amount of $\mathrm{CO}_{2}$ was detected as a by-product (Run 1).

High CO conversion of about $20 \%$ was obtained over the chlorine-free magnetite catalyst $\left(\mathrm{Fe}_{3} \mathrm{O}_{4}\right.$; Run 3). Substantial amount of methane, $\mathrm{C}_{2}-\mathrm{G}_{5}$ paraffins, and $\mathrm{CO}_{2}$ were produced.

The results over other chlorine-containing magnetite catalysts are also summarized in Table 1 (Run 4-6). Since the activity of each catalyst was different, GHSV was adopted in such a manner that the conversion, excluding $\mathrm{CO}_{2}$ could be adjusted in the range of $5-20 \%$. Lower selectivity to light olefins and higher selectivity to methane were observed over the magnetite catalyst prepared by ammonium co-precipitation $\left(\mathrm{NH}_{3} \downarrow \mathrm{Fe}_{3} \mathrm{O}_{4}\right.$; Run 4) and over the catalyst prepared from akaganeite $(\beta-\mathrm{FeOOH}$; Run 6$)$ than those over the $\mathrm{Cl} / \mathrm{Fe}_{3} \mathrm{O}_{4}$ 
Table 1 Hydrogenation of Garbon Monoxide over Chlorine-Containing Magnetite Catalysts in Slurry Phase

\begin{tabular}{|c|c|c|c|c|c|c|}
\hline Run & 1 & 2 & 3 & 4 & 5 & 6 \\
\hline $\begin{array}{l}\text { Catalyst } \\
\text { Preparation } \\
\mathrm{H}_{\mathbf{2}} \text { Treatment }{ }^{\mathrm{a})} \quad\left({ }^{\circ} \mathrm{C}\right)\end{array}$ & $\begin{array}{l}\mathrm{Cl} / \mathrm{Fe}_{3} \mathrm{O}_{4} \\
\text { reflux } \\
\quad 400\end{array}$ & $\begin{array}{l}\mathrm{Cl} / \mathrm{Fe}_{3} \mathrm{O}_{4} \\
\text { reflux } \\
-\end{array}$ & $\begin{array}{l}\mathrm{Fe}_{3} \mathrm{O}_{4} \\
\text { air- } \\
\text { oxidation } \\
-\end{array}$ & $\begin{array}{c}\mathrm{NH}_{3} \downarrow \mathrm{Fe}_{3} \mathrm{O}_{4} \\
\text { ammonium } \\
\text { coprecipitation } \\
-\end{array}$ & $\begin{array}{c}\mathrm{Cl- \textrm {Fe } _ { 3 } \mathrm { O } _ { 4 }} \\
\text { chloridized } \\
350\end{array}$ & $\begin{array}{c}\beta-\mathrm{FeOOH} \\
\text { akaganeite } \\
350\end{array}$ \\
\hline $\begin{array}{c}\text { GHSV }(\mathrm{hr}-1) \\
\mathrm{CO} \text { Conv. }(\%) \\
\mathrm{CO}_{2} \mathrm{Yield}(\%) \\
\text { Selectivity }(\mathrm{C}-\%) \\
\mathrm{CH}_{4}(\%) \\
\mathrm{C}_{2} \mathrm{H}_{4} \\
\mathrm{C}_{2} \mathrm{H}_{6} \\
\mathrm{C}_{3} \mathrm{H}_{6} \\
\mathrm{C}_{3} \mathrm{H}_{8} \\
\mathrm{C}_{4} \mathrm{H}_{8} \\
\mathrm{C}_{4} \mathrm{H}_{10} \\
\mathrm{C}_{5} \mathrm{H}_{10} \\
\mathrm{C}_{5} \mathrm{H}_{12} \\
\text { total } \\
\mathrm{C}_{2} \text { - } \mathrm{C}_{4} \text { Olefin } \\
\text { Paraffin/Olefin }\left(\mathrm{C}_{2}-\mathrm{C}_{5}\right)\end{array}$ & $\begin{array}{r}2,000 \\
8.6 \\
0.4 \\
\\
11.1 \\
10.9 \\
3.5 \\
20.6 \\
1.4 \\
16.8 \\
1.1 \\
8.5 \\
0.8 \\
74.7 \\
48.3 \\
0.12\end{array}$ & $\begin{array}{r}2,000 \\
1.6 \\
0.1 \\
=-b \\
= \\
= \\
= \\
= \\
= \\
= \\
=\end{array}$ & $\begin{array}{r}2,000 \\
19.6 \\
4.8 \\
\\
21.5 \\
4.8 \\
11.9 \\
16.5 \\
5.2 \\
9.0 \\
1.8 \\
3.7 \\
1.0 \\
75.3 \\
30.3 \\
0.59\end{array}$ & $\begin{array}{r}2,000 \\
21.1 \\
3.8 \\
\\
16.5 \\
7.7 \\
5.3 \\
16.4 \\
1.6 \\
10.5 \\
1.0 \\
5.5 \\
2.8 \\
67.2 \\
34.6 \\
0.27\end{array}$ & $\begin{array}{r}1,000 \\
6.0 \\
0.1 \\
11.3 \\
10.5 \\
1.4 \\
17.0 \\
0.9 \\
11.6 \\
0.7 \\
5.7 \\
1.5 \\
60.6 \\
39.1 \\
0.10\end{array}$ & $\begin{array}{r}5,000 \\
8.7 \\
1.5 \\
\\
22.5 \\
7.6 \\
8.7 \\
15.8 \\
3.0 \\
7.7 \\
1.6 \\
3.6 \\
3.2 \\
73.6 \\
31.1 \\
0.48\end{array}$ \\
\hline $\begin{array}{l}\text { Residual } \mathrm{Cl} \text { in used } \\
\text { Catal. (Cl/Fe) } \\
\text { BET Area (m² } / \mathrm{g} \text { ) } \\
\text { Bulk Composition of used } \\
\text { Catalyst Identified by XRD })\end{array}$ & $\begin{array}{l}0.002 \\
32 \\
\end{array}$ & $\begin{array}{l}0.07 \mathrm{c}) \\
32 \\
\Phi(\mathrm{s}) \\
\Phi(\mathrm{w})\end{array}$ & $\begin{array}{l}<0.001 \\
37 \\
(\mathrm{~s}) \\
(\mathrm{m})\end{array}$ & $\begin{array}{l}0.01 \\
15 \\
\end{array}$ & $\begin{array}{l}0.01 \\
18 \\
(\mathrm{~d}) \\
(\mathrm{w})\end{array}$ & $\begin{array}{l}0.003 \\
14 \\
(\mathrm{~s}) \\
(\mathrm{w})\end{array}$ \\
\hline
\end{tabular}

Reaction conditions : $P=10$ atm, $T=325^{\circ} \mathrm{C}, \mathrm{H}_{2} / \mathrm{CO}=1$.

a) The pretreatment was carried out outside the reactor.

b) The conversion was too low to calculate selectivity.

c) Chlorine content in the fresh catalyst.

d) $\mathrm{Fe}_{3} \mathrm{O}_{4} ; \mathrm{O}, \mathrm{Fe}$-carbide; $(1, \mathrm{FeOOH}$; s, strong; m, medium; w, weak.

catalyst. Over these catalysts the formation of $\mathrm{CO}_{2}$ was generally depressed.

\subsection{Analysis of Used Catalyst}

The chlorine contents in the used catalysts were determined by X-ray fluorescence spectrometry, and the $\mathrm{Cl} / \mathrm{Fe}$ atomic ratios of them are listed in Table 1. The chlorine content in the fresh $\mathrm{Cl} /$ $\mathrm{Fe}_{3} \mathrm{O}_{4}$ catalyst was found to be $\mathrm{Cl} / \mathrm{Fe}=0.07$ ( $\mathrm{Run} 2$ ). A trace amount of chlorine of $\mathrm{Cl} / \mathrm{Fe}=0.002$ still remained after the $\mathrm{H}_{2}$ pretreatment followed by CO hydrogenation (Run 1). The residual chlorine contents in the other used catalysts (Run 4-6) were in the range of $\mathrm{Cl} / \mathrm{Fe}=0.003-0.01$.

The BET areas of the fresh catalysts were in the range of $14-37 \mathrm{~m}^{2} / \mathrm{g}$.

The $\mathrm{Cl} / \mathrm{Fe}_{3} \mathrm{O}_{4}$ catalyst was confirmed by XRD to maintain the magnetite structure even after $\mathrm{H}_{2}$ pretreatment and $\mathrm{CO}$ hydrogenation (Run 1). The $\mathrm{NH}_{3} \downarrow \mathrm{Fe}_{3} \mathrm{O}_{4}$ catalyst and the chloridized catalyst $\left(\mathrm{Cl}-\mathrm{Fe}_{3} \mathrm{O}_{4}\right)$ were also found to maintain the magnetite structure after reaction (Runs 4 and 5). On the contrary, small peaks corresponding to iron carbides were detected by XRD in the used chlorinefree $\left(\mathrm{Fe}_{3} \mathrm{O}_{4} ; \mathrm{Run} 3\right)$ and $\beta-\mathrm{FeOOH}$ (Run 6) catalysts.

\subsection{XPS of $\mathrm{Cl} / \mathrm{Fe}_{3} \mathrm{O}_{4}$}

The XPS results corresponding to $\mathrm{Fe} 2 \mathrm{p}$ and $\mathrm{Cl}$
$2 \mathrm{p}$ bands of fresh and used $\mathrm{Cl} / \mathrm{Fe}_{3} \mathrm{O}_{4}$ catalysts as well as of ferrous chloride, for comparison, are summarized in Table 2. The binding energies of Fe $2 p_{3 / 2}$ and $\mathrm{Cl} 2 \mathrm{p}_{3 / 2}$ bands were corrected by using the $\mathrm{C}$ ls band of adsorbed carbon on the samples as an internal standard at $285.0 \mathrm{eV}$. The binding energies of ferrous chloride were almost identical to those reported in literature ${ }^{9), 10)}$. The binding energies of $\mathrm{Fe} 2 \mathrm{p}_{3 / 2}$ of fresh and used catalysts indicate that the valency of $\mathrm{Fe}$ on the catalysts was approximately 3 . The $\mathrm{Cl} 2 \mathrm{p}_{\mathbf{3} / \mathbf{2}}$ bands of these catalysts, on the other hand, shifted toward lower binding energy side than the band of ferrous chloride by $0.6-0.9 \mathrm{eV}$. This shift suggests that the valence state of chlorine on the catalysts was almost the same as that of alkali halides ${ }^{11)}$, and that the chlorine was more negatively charged than that of iron chlorides.

From the peak intensity ratio $(\mathrm{Cl} / \mathrm{Fe})$, the surface concentration of chlorine of the $\mathrm{Cl} / \mathrm{Fe}_{3} \mathrm{O}_{4}$ catalyst is estimated to be $\mathrm{Cl} / \mathrm{Fe}=0.1-0.2$ (atomic ratio) including the experimental errors, as shown in Table 2. The value was higher than the chlorine contents determined by X-ray fluorescence spectrometry. After $\mathrm{H}_{2}$ pretreatment and reaction, the surface concentration did not change so much as the inside concentration, which decreased from 
Table 2 Binding Energy and Surface Concentration of Chlorine on $\mathrm{Cl} / \mathrm{Fe}_{3} \mathrm{O}_{4}$ Catalysts

\begin{tabular}{|c|c|c|c|c|c|}
\hline & \multicolumn{2}{|c|}{ Binding Energy* } & \multicolumn{2}{|c|}{$\mathrm{Cl} / \mathrm{Fe}$} & \multirow[b]{2}{*}{ Literature } \\
\hline & $\mathrm{Fe} 2 \mathrm{p}_{3 / 2}$ & Cl $2 \mathrm{p}_{3 / 2}$ & $\begin{array}{c}\text { peak } \\
\text { intensity } \\
\text { ratio }\end{array}$ & $\begin{array}{c}\text { surface } \\
\text { concentration } \\
\text { (atomic ratio) }\end{array}$ & \\
\hline \multirow{2}{*}{$\begin{array}{l}\text { Fresh Catalyst } \\
\text { (before } \mathrm{H}_{2} \text { pretreatment) } \\
\text { Used Catalyst } \\
\text { FeCl }_{2} \text { (this study) }\end{array}$} & $711.4 \mathrm{eV}$ & $198.4 \mathrm{eV}$ & 0.06 & $0.16 \pm 0.05$ & \\
\hline & $\begin{array}{l}711.4 \\
710.5\end{array}$ & $\begin{array}{l}198.7 \\
199.3\end{array}$ & $\begin{array}{l}0.05 \\
0.89\end{array}$ & $\begin{array}{l}0.13 \pm 0.05 \\
2.3 \pm 0.6\end{array}$ & \\
\hline $\begin{array}{l}\mathrm{FeO} \\
\mathrm{Fe}_{2} \mathrm{O}_{3}\end{array}$ & $\begin{array}{l}710.3 \\
711.4\end{array}$ & & & & 8) \\
\hline $\begin{array}{l}\mathrm{FeOOH} \\
\mathrm{FeCl}_{2} \\
\mathrm{FeCl}_{3} \\
\mathrm{LiCl} \\
\mathrm{NaCl} \\
\mathrm{KGl}\end{array}$ & $\begin{array}{l}711.0 \\
710.8 \\
711.5\end{array}$ & $\begin{array}{l}199.0 \\
199.2 \\
198.7 \\
198.4 \\
198.3\end{array}$ & & & $\begin{array}{l}\text { 8) } \\
9), 10) \\
11) \\
11) \\
11)\end{array}$ \\
\hline
\end{tabular}

* Values referenced to adsorbed carbon with $\mathrm{C} 1 \mathrm{~s}=285.0 \mathrm{eV}$.

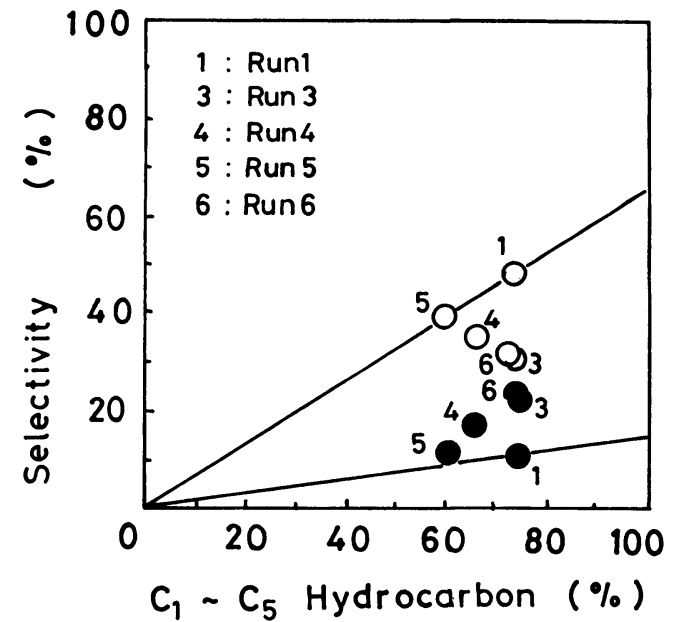

Fig. 1 Selectivity to Methane (O) and to $\mathrm{C}_{2}-\mathrm{C}_{4}$ Olefins (O) against Selectivity to the Total Gaseous Hydrocarbons over Magnetite Catalysts in Table 1

$\mathrm{Cl} / \mathrm{Fe}=0.07$ to 0.002 , as mentioned above.

\section{Discussion}

\subsection{Product Pattern}

When the selectivities to methane and $\mathrm{C}_{\overline{2}} \overline{\overline{2}}-\mathrm{C}_{\mathbf{4}}=$ were plotted against the selectivity to gaseous hydrocarbons $\left(\mathrm{C}_{\mathbf{1}}-\mathrm{G}_{5}\right)$, the results in Table $\mathbf{1}$ could be depicted as shown in Fig. 1. As for the results over $\mathrm{Cl} / \mathrm{Fe}_{3} \mathrm{O}_{4}$ and $\mathrm{Cl}-\mathrm{Fe}_{3} \mathrm{O}_{4}$ (Runs 1 and 5, Fig. 1), each point was almost aligned on the same line passing through the origin. When the lines were extrapolated to $100 \%$ of gaseous hydrocarbons, the intercepts at $15 \%$ and $65 \%$ indicated the selectivities to methane and $\mathrm{C}_{\mathbf{3}}-\mathrm{C}_{\mathbf{4}}=$ in the gaseous hydrocarbons, respectively.

By applying the same analysis to other catalysts, deviations from the lines indicated that the product patterns on the catalysts were different from the pattern on the $\mathrm{Cl} / \mathrm{Fe}_{3} \mathrm{O}_{4}$ catalyst $^{12)}$, and that the selectivity to methane was higher, and the selectivity to $\mathrm{C}_{\mathbf{2}}=\mathrm{C}_{\mathbf{4}}=$ was lower for the other catalysts than for the above two catalysts.

Thus, by this analysis, the catalysts could be classified into two groups, Runs 1 and 5 (group 1), and Runs 4 and 6 (group 2). The hydrogenation activity was higher for group 2 than for group 1 .

In any case, the selectivity over the chlorinecontaining magnetite catalysts was characterized as follows :

1) Only a trace amount of $\mathrm{CO}_{2}$ was produced as a by-product.

2) Methane formation was suppressed.

3) Selectivity to gaseous hydrocarbons was high. Consequently,

4) Relatively high selectivity to light olefins was accomplished.

And these characteristics were distinctive over the $\mathrm{Cl} / \mathrm{Fe}_{3} \mathrm{O}_{4}$ catalyst. The lower selectivity to olefins for group 2 catalysts indicated that chlorine might not be distributed uniformly on the surface of the catalyst, and the chlorine distributed inside catalyst was not so effective for improving the olefin selectivity as group 1 catalysts.

\subsection{Oxidation State of Catalyst and Olefin Selectivity}

Iron carbides were scarcely detected by XRD in the used catalysts belonging to group 1 . On the other hand, some of the catalysts of group 2 were carburized during the reaction. It is suggested that, based on this result and the product pattern, paraffin selectivity correlates to the carburization of the catalyst. It is reported that metallic iron is rapidly carburized during the reaction, and that methane selectivity is high on 


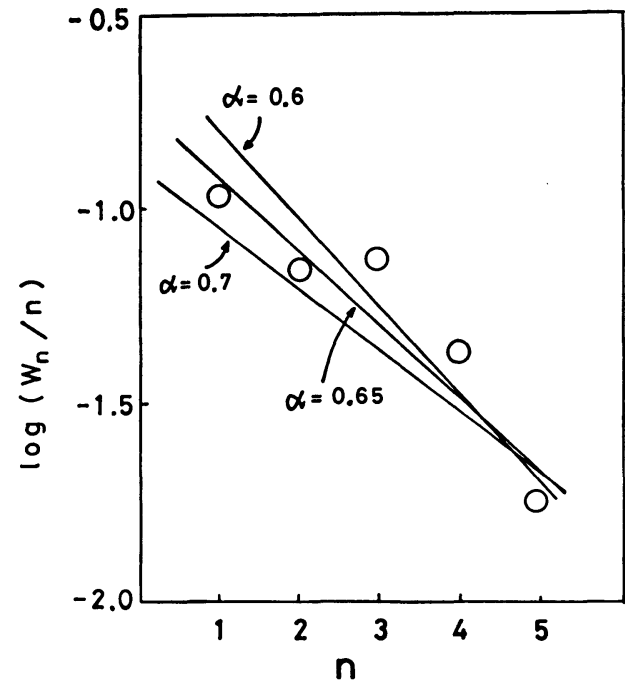

The lines are predicted by the Schulz-Flory polimerization law at $\alpha=0.6,0.65$ and 0.7 , respectively.

Fig. 2 Schulz-Flory Plot over $\mathrm{Cl} / \mathrm{Fe}_{3} \mathrm{O}_{4}$ Catalyst

the surface. ${ }^{7)}$

The XPS results of the $\mathrm{Cl} / \mathrm{Fe}_{3} \mathrm{O}_{4}$ catalyst showed that the chlorine on the catalyst surface was more negatively charged than that of iron chloride, and that the electron density of $\mathrm{Fe}$ on the surface decreased. The $\mathrm{Cl} / \mathrm{Fe}_{3} \mathrm{O}_{4}$ catalyst was not easily reduced to metallic iron by $\mathrm{H}_{2}$ treatment. These results indicate that the surface of the catalyst was maintained by chlorine to be oxidative.

Carbon dioxide, a by-product, was hardly produced over the catalyst. It is implied that the water gas shift reaction (WGSR) was prevented by chlorine. It is reported that WGSR can proceed only when the surface iron can be partially reduced by $\mathrm{CO} .{ }^{13)}$ Low yield of $\mathrm{CO}_{2}$ supports the fact that over-reduction of the surface is prevented.

The same effect of halogen is also reported on $\mathrm{Rh}$ catalysts in $\mathrm{CO}$ hydrogenation to acetic acid, where $\mathrm{Rh}$ was not metallic but in a low valence state $(+1 \sim 2)$ maintained by halide ion. These catalysts improved selectivity to acetic acid to $76 \%$ and suppressed the formation of highly hydrogenated products, such as methane, ethanol and acetaldehyde. ${ }^{14)}$ This suppression is considered stemming from reduction in the hydrogenation activity of the catalysts.

Basing on these results, the high selectivities to olefins of the chlorine-containing magnetite catalysts reflect their low hydrogenation activities brought about by their surface chlorine. The suppression of methane formation may be explained in the same way. Fujimoto et. al. proposed the same explanation for the increase in olefin selectivity by silica-supported $\mathrm{Rh}$ catalysts by addition of halides to or $\mathrm{HCl}$ treatment of the catalysts. ${ }^{15}$ )

\subsection{Molecular Weight Distribution}

The product distribution over $\mathrm{Cl} / \mathrm{Fe}_{3} \mathrm{O}_{4}$ catalyst was depicted in Fig. 2. The selectivity to $\mathrm{C}_{3}$ and $\mathrm{C}_{4}$ deviated upward from the line predicted by the Schulz-Flory distribution rule. Since the cracking of the slurry solvent was almost negligible, the deviation cannot be attributed to cracking. Such high selectivity could not be realized in a fixed-bed reactor, as reported earlier. ${ }^{3}$ ) The uniform surface temperature of the catalyst in the slurry phase is considered to be the main reason for such high selectivity. Hot spots in fixed-bed system may induce partial desorption of the surface chlorine to reduce selectivity.

The $\mathrm{Cl} / \mathrm{Fe}_{3} \mathrm{O}_{4}$ catalyst was hardly carburized during the reaction in the slurry phase as shown in Table 1. This result suggests that the surface of the catalyst is maintained unchanged and side reactions scarcely occurred. Thus, the high selectivity of the $\mathrm{Cl} / \mathrm{Fe}_{3} \mathrm{O}_{4}$ catalyst was attained in the slurry phase.

The reaction temperature in this study was higher than the conventional FT reaction over iron type catalysts. ${ }^{2}$ It is reported that high temperatures are desirable for increasing the selectivity to light hydrocarbons. ${ }^{16}$ ) Metallic iron catalysts are, however, unstable at high temperatures, and they are rapidly converted into carbides and lose their FT activity. ${ }^{1)}$ On the contrary, magnetite catalysts can be used at high temperatures provided the iron in the catalysts is maintained to be oxidative. ${ }^{7)}$ The role of the chlorine in the catalysts is, then, to maintain the oxidation state of the catalyst surface.

Another role of the chlorine may be assumed in limiting the product distribution. The electronic effect, which was ascertained by XPS, of the chlorine is in the opposite direction to that of potassium promoters as is generally accepted. ${ }^{17)}$ Potassium promoters are electron donative, whereas chlorine is electron attractive. It is well known that the product distribution shifts toward higher molecular weights by the addition of potassium salts to FT catalysts. For a similar reason, the selectivity to light hydrocarbons might increase in the opposite direction over the $\mathrm{Cl} / \mathrm{Fe}_{3} \mathrm{O}_{4}$ catalyst. The increase in the light hydrocarbon selectivity is also reported in some patents when easily decomposable halides were added to syngas ${ }^{18}$ ) or when the catalysts were 
treated with chlorides. ${ }^{19), 20)}$

Thus, high selectivity to $\mathrm{C}_{\mathbf{3}}-\mathrm{C}_{\mathbf{4}}$ over the catalysts was accomplished by the two effects of chlorine (the limitation of product distribution and the suppression of methane formation), as mentioned above. The detailed characterization of the chlorine on the surface of the catalyst is now in progress, and it will be reported in another paper.

This work is a part of " $\mathrm{C}_{1}$ Chemistry Project", a National Research and Development Program of Agency of Industrial Science and Technology, Ministry of International Trade and Industry (M. I.T.I.), Japan.

\section{References}

1) Okabe, K., Suzuki, K., Ogawa, K., Saitoh, K., Shimomura, K., Araki, M., Takaya, H., Bandoh, K., Takami, Y., Sekiyu Gakkaishi, 28, 187 (1985).

2) Dry, M. E., Catal. Sci. Tech., 1, 159 (1981).

3) Okabe, K., Sano, T., Yanagisawa, H., Araki, M., Shimomura, K., Ogawa, K., Hosoya, T., Takaya, H., Bandoh, K., Sekiyu Gakkaishi, 28, 176 (1985).

4) Kandori, K., Kitahara, A., Kon-no, K., Nippon Kagaku Kaishi, 1982, 722.

5) Paterson, E., Swaffield, R., Clark, D. R., Thermo Chemica Acta, 54, 201 (1982).
6) Tamaura, Y., Buduan, P. V., Katsura, T., J. C. S. Dalton, 1981, 1807.

7) Okabe, K., Sano, T., Saitoh, K., Hagiwara, H., Araki, M., Shimomura, K., Ogawa, K., Hosoya, T., Takaya, H., Bandoh, K., Sekiyu Gakkaishi, 28, 148 (1985).

8) Allen, G. C., Curtis, M. T., Hooper, A. J., Tucker, P. M., J. C. S. Dalton, 1974, 1525.

9) Carver, J. G., Schweitzer, G. K., J. Chem. Phys., 57, 973 (1972).

10) Kishi, K., Ikeda, S., J. Phys. Chem., 78, 107 (1974).

11) Morgan, W. E., Van Wazer, J. R., Stec, W. J., J. Amer. Chem. Soc., 95, 751 (1973).

12) Sano, T., Yanagisawa, H., Okabe, K., Hagiwara, H., Yasumoto, Y., Okado, H., Takaya, H., Bull. Chem. Soc. Jpn., 58, 1317 (1985).

13) Newsome, D. S., Catal. Rev. Sci. Eng., 21, 275 (1980).

14) Japan Kokai $818,334$. Japan Kokai 79 141, 705. Japan Kokai 79 138, 504.

15) Fujimoto, K., Kameyama, M., Abe, Y., Kunugi, T., Sekiyu Gakkaishi, 24, 233 (1981).

16) Büssemeier, B., Frohning, C. D., Cornils, B., Hydrocarbon Processing, Nov., 105 (1976).

17) Dry, N. E., Shingles, T., Boshoff, L. J., Oosthuizen, G. J., J. Catal., 15, 190 (1969).

18) U. S. 2, 717, 259.

19) Hammer, H., Bittner, D., Erdöl. Kohle Erdogas Petrochem. Bren. Chem., 31, 369 (1978).

20) U. S. $4,172,842$. U. S. $4,252,685$. 
要旨

\author{
スラリー法による塩素含有マグネタイト触媒上での \\ 一酸化岸素の軽質オレフィンへの水素化 \\ 岡部 清美 ${ }^{\dagger 1}$, 斉藤 健二 ${ }^{\dagger 2}$, 佐野 庸治 ${ }^{\dagger 1)}$, 安本 義郎 ${ }^{\dagger 1)}$, 下村 欣也 ${ }^{\dagger 1)}$, \\ 萩原 弘之 ${ }^{\dagger 1}$, 高谷 晴生 ${ }^{\dagger 1)}$, 阪東憲一郎 ${ }^{\dagger 1)}$ \\ †1) 化学技術研究所工業触媒部, 305 茨城県筑波郡谷田部町東 1-1 \\ †2) 丸善石油化学(株), 104 東京都中央区八丁堀 2-25-10
}

金属鉄の存在下で塩化第二鉄水溶液を還流することによって 得られるマグネタイト4)を $400^{\circ} \mathrm{C}$ で水素処理したもの（以下， $\mathrm{Cl} / \mathrm{Fe}_{3} \mathrm{O}_{4}$ と略）を触媒として用い，スラリー法で Fischer$\operatorname{Tropsch}(\mathrm{FT})$ 反応を行った。反応条件は, $T=325^{\circ} \mathrm{C}, P=10$ atm, GHSV $=1,000 \sim 5,000 \mathrm{hr}^{-1}, \mathrm{H}_{2} / \mathrm{CO}=1$ とし, 前報7) で 述べた方法により，生成物の分析を行った。反応気体に添加し た Ar を内部標準として，CO 転化率および炭素数基準の選択 率を求めた（Eqs. (1)〜 ( 3$)$ )。また，他の方法で調製した塩 素含有マグネタイト触媒とも比較した。

触媒に含まれる塩素の酸性により，スラリ一媒体のクラッキ ングが起こり，反応結果に影響することが懸念されるが，ブラ ンク試験の結果, 反応条件の範囲内では，この影響はほとんど 無視できることがわかった。

塩化鉄から還流法で調製したマグネタイトには，原料に起因 する塩素の残留が認められ，その量は $\mathrm{Fe}$ に対する原子比で 0.07 程度であった。このままのマグネタイト触媒は残留塩素 の毒作用によってほとんど活性を示さないが, $400^{\circ} \mathrm{C}$ で水素処 理することにより触媒中の塩素が 0.002 程度にまで除かれ， 活性が得られた。この触媒上では, 他の方法で調製した塩素含 有マグネタイト触媒よりも高い低級オレフィン $\left(\mathrm{C}_{\overline{\mathbf{2}}} \sim \mathrm{C}_{\overline{\mathbf{4}}}\right)$ 選択 率 (48\%) が得られた。また， $\mathrm{CO}_{2}$ の副生がほとんどなく， メタンの生成が $11 \%$ にまで抑制され, 気相炭化水素選択率が 高かった。なお, 反応後のこの触媒のバルクの組成は, $\mathrm{Fe}_{3} \mathrm{O}_{4}$ のままであった (Table 1)。

反応前後に打ける $\mathrm{Cl} / \mathrm{Fe}_{3} \mathrm{O}_{4}$ 触媒の $\mathrm{Fe} 2 \mathrm{p}$ および $\mathrm{Cl} 2 \mathrm{p}$ に対応する XPS の測定結果から, 反応前後とも, 触媒表面の 塩素の電子密度は塩化鉄よりも大きく, $\mathrm{Fe}$ の電子密度を 減少 させていることが示唆された。また，水素処理および反応の前
後で触媒バルクの塩素量は大きく変化するにもかかわらず, 触 媒表面の塩素濃度はほぼ一定で, $\mathrm{Cl} / \mathrm{Fe}=0.1 \sim 0.2$ 程度と推定 された。この值は, バルクの塩素量よりはるかに大きいといえ る (Table 2)。

メタン選択率あるいは $\mathrm{C} \overline{\overline{2}} \sim \mathrm{C}=$ 選択率を気相炭化水素選択率 に対してプロットするという解析法12)を用い, 生成物パター ンを比較した。その結果, 塩素化したマグネタイト触媒 $(\mathrm{Cl}-$ $\left.\mathrm{Fe}_{3} \mathrm{O}_{4}\right)$ は $\mathrm{Cl} / \mathrm{Fe}_{3} \mathrm{O}_{4}$ 触媒と類似した生成物パターンを有する が，他の塩素含有マグネタイト触媒は異なるパターンを示すこ とが見い出された (Fig. 1)。

塩素含有マグネタイト触媒では，水性ガス転化反応がほとん ど進行しないこと, および, $400^{\circ} \mathrm{C}$ の水素処理でも触媒が金属 鉄まで還元されないこと，さらに，XPS の結果等から，塩素 の電子吸引効果により, 触媒表面が金属的になりにくく, 水素 化能が低下して, メタンをはじめとするパラフィン生成が抑制 されたものと思われる。

$\mathrm{Cl} / \mathrm{Fe}_{3} \mathrm{O}_{4}$ 触媒では Schulz-Flory 則から予測される值より も高い $\mathrm{C}_{3}$ および $\mathrm{C}_{\mathbf{4}}$ 選択率が得られた (Fig. 2)。その原因 として，まず，スラリー法で反応を行ったため触媒層温度が均 一に保たれ，副反応や塩素の部分的な脱離が防止できたことが 考えられる。さらに, 残留塩素の効果により触媒表面が金属的 になりにくく，高温での反応が可能で，そのために，生成物分 布が低分子側に偏ったものと思われる。また，塩素の電子的効 果はカリウムとは逆方向であり，したがって，分子量分布が低 分子側に偏ったものと思われる。その上，残留塩素に起因する 水素化能抑制によりメタン生成が抑制されたため, 高い低級オ レフィン選択率が得られたのであろら。

\title{
Keywords
}

Carbon monoxide, Chlorine, Fischer-Tropsch synthesis, Light olefin, Magnetite, Slurry phase 